\title{
PENGARUH BUDAYA PERUSAHAAN TERHADAP PRESTASI KERJA KARYAWAN PT PEMBANGKITAN JAWA-BALI SURABAYA UNIT PELAYANAN PEMELIHARAAN
}

\author{
Riyan Sisiawan Putra \\ Universitas Nadhlatul Ulama, Surabaya \\ Email: riyan_sisiawan@yahoo.com
}

\begin{abstract}
Abstrak
Penerapan budaya perusahaan yang kuat akan mempercepat perusahaan mencapai hasil yang lebih baik, sehingga akan meningkatkan kesejahteraan karyawan. Tujuan penelitian ini adalah untuk mengetahui hubungan antar variabel budaya perusahaan, motivasi kerja dan prestasi kerja karyawan.Teknik analisis yang digunakan adalah Path Analysis.Hasil penelitian ini menunjukkan terdapat pengaruh yang signifikan variabel budaya perusahaan terhadap motivasi kerja, budaya perusahaan terhadap prestasi kerja karyawan dan motivasi kerja terhadap prestasi kerja karyawan PT Pembangkitan Jawa-Bali Surabaya unit pelayanan pemeliharaan.
\end{abstract}

Kata kunci: Budaya perusahaan, motivasi kerja, prestasi kerja.

\begin{abstract}
A strong application of corporate culture drives a company in improving its performance and achieving its targets. With the result that the corporate culture has a role in increasing the welfare of it's employees. The purpose of this study was to determine the relationship between the variables of corporate culture, employee motivation and employee performance. Path Analysis technique was utilised to analyse the obtained data. The results showed significant influences between work motivation on corporate culture, corporate culture on employee performance and work motivation on employee performance of PT Power Java-Bali, maintenance services unit of Surabaya.
\end{abstract}

Keywords: Corporate culture, work motivation, work performance.

\section{PENDAHULUAN}

Semakin berkembangnya teknologi, membuat perusahaan-perusahaan beradaptasi dalam menggunakannya. Begitu juga dalam hal sumber daya manusia, teknologi tidak akan berjalan tanpa adanya sumber daya manusia yang berkualitas. Mengetahui akan pentingnya kebutuhan sumber daya manusia ini membuat perusahaan berfikir, bagaimana membuat sumber daya manusia yang berprestasi dalam pekerjaannya. Melihat hal tersebut, sumber daya manusia merupakan asset yang sangat penting bagi perusahaan, yang mana apabila sumberdaya daya manusia tersebut bekerja dengan bagus, maka keuntungannya akan kembali ke perusahaan.

Schein dalam Caudron (2003), menyatakan bahwa hanya perusahaan yang memiliki sumber daya manusia yang berkualitas akan mampu bersaing dalam persaingan global. Untuk mengelola sumber daya manusia yang berkualitas, tangguh, serta terkoordinasi dengan baik perlu diperlukan teknik manajemen yang baik pula.
Penciptaan sumber daya manusia yang berkualitas dalam konteks strategic planning atau kebijakan strategis perusahaan, ternyata pelaksanaan dari praktek manajemen sumber daya manusia diatas dirasakan belum mencukupi. Salah satu kebijakan strategis internal yang dapat ditempuh pihak manajemen organisasi dalam mengoptimalkan kualitas serta prestasi karyawan adalah dengan melakukan pemberdayaan dan sosialisasi dari corporate culture atau budaya perusahaan.

Menurut Atmosoeprapto (2001)budaya perusahaan atau budaya kerja, memang sulit didefinisikan secara tegas dan sulit diukur, namun bisa dirasakan oleh karyawan di dalam perusahaan tersebut. Oleh karena itu suatu organisasi terbentuk dari kumpulan individu yang berbeda baik sifat, karakter, keahlian, pendidikan dan latar belakang pengalaman dalam hidupnya, perlu adanya pengakuan pandangan yang berguna untuk pencapaian misi dan organisasi tersebut.

Diatas telah disinggung tentang masalah teknologi, apabila ditinjau secara umum teknologi 
merupakan pengaruh lingkungan internal dari perusahaan dan disini akan dibahas tentang budaya perusahaan baik itu yang dipengaruhi dari luar seperti perubahan sistem ekonomi, pengaruh ekonomi baik nasional maupun internasional serta perubahan kondisi hukum dan peraturan. Yang mana perubahan yang berasal dari dalam bisa disebabkan oleh terjadinya perubahan teknologi, perubahan struktur manajemen yaitu pergantian manajer puncak dan terjadinya (merger) dengan perusahaan lain.

Adanya perubahan-perubahan tersebut membuat perusahaan berpikir supaya bisa mengelola sumber daya manusianya untuk bisa tetap berprestasi dalam pekerjaannya. Menurut Newstrom \& Davis (2002) merupakan refleksi dari organisasi formal maupun informal yang terbentuk didalam organisasi yang bersangkutan, yang kesemuanya itu membentuk norma-norma kepercayaan atau persepsi bersama yang nantinya dianut oleh seluruh anggota organisasi.

Menurut Robbins, (2003) motivasi adalah kondisi internal yang spesifik dan mengarahkan perilaku seseorang ke suatu tujuan. Yang mana Siagian (2006) mendefinisikan motivasi sebagai daya pendorong yang menyebabkan seseorang individu mau dan rela untuk mengerahkan kemampuan melakukan kegiatan yang menjadi tanggung jawabnya. Dari pengertianpengertian diatas dapat disimpulkan bahwa budaya berfungsi sebagai tools atau alat bagi perusahaan dalam menjalankan kebijaksanaan strategis yang berperan dalam mendorong, meningkatkan kualitas, motivasi serta prestasi kerja karyawan.

Karyawan PT Pembangkitan Jawa-Bali (PJB) Surabaya unit pelayanan pemeliharaan bertugas untuk mengontrol pembangkitan-pembangkitan yang ada di Jawa-Bali dan melakukan perbaikan-perbaikan apabila terdapat kerusakan pada pembangkitan-pembangkitan tersebut. PT Pembangkitan Jawa Bali (PJB) merupakan perusahaan yang bergerak dalam bidang listrik juga menganggap penting mengenai budaya perusahaan. PJB mempunyai lima nilai dasar budaya yang menjadi acuan perilaku seluruh insan perusahaan secara terus-menerus yang akhirnya akan membentuk budaya perusahaan PJB. Penerapan budaya perusahaan yang kuat akan mempercepat perusahaan mencapai hasil yang lebih baik, sehingga akan meningkatkan kesejahteraan karyawan. Slogan budaya perusahaan PJB adalah Produsen Listrik Terpercaya dan nilai-nilai dasar budaya PJB, yaitu:

1. Integritas

a. Jujur. Menjunjung tinggi kejujuran dan etika kerja sesuai dengan peraturan perusahaan yang berlaku serta dapat menjadi contoh bagi lingkungannya. b. Dedikasi. Bekerja dengan sasaran dan usaha yang sangat tinggi melebihi sasaran dan usaha orang lain pada umumnya.

c. Konsisten. Bekerja sesuai dengan deskripsi kerja, menepati komitmen, disiplin dan tidak menunda pekerjaan.

\section{Keunggulan}

a. Ide. Mampu mendorong terciptanya suatu ide yang kreatif dan inovatif dalam bekerja.

b. Efisien. Memanfaatkan sumberdaya yang tersedia secara efisien untuk memberikan kontribusi yang optimal.

c. Efektif. Bekerja dengan orientasi pada hasil yang berkualitas tinggi.

3. Kerjasama

a. Apresiasi. Menghargai kontribusi yang diberikan oleh setiap orang dalam kerangka tujuan bersama.

b. Pembelajaran Bersama. Berusaha selalu menambah ilmu melalui barbagai cara, serta bersedia berbagi ilmu dan pengalaman yang dimiliki kepada orang lain.

c. Aktif Terlibat. Aktif terlibat dalam setiap aktivitas kelompok kerja dengan penuh tanggung jawab dan kerelaan berkorban demi tujuan bersama.

4. Pelayanan

a. Motivasi. Melayani pelanggan dengan motivasi tinggi dan mampu memotivasi orang lain dalam bekerja.

b. Perbaikan Berkelanjutan. Terus menerus memikirkan dan memberikan ide untuk melakukan perbaikan terhadap sistem dan cara kerja pelayanan.

c. Cepat Tanggap. Cepat tanggap terhadap keluhan pelanggan dan berusaha mengatasinya.

5. Sadar Lingkungan

a. Lingkungan Hidup. Mempunyai komitmen yang tinggi terhadap kualitas lingkungan hidup dan kelestariannya.

b. Lingkungan Masyarakat. Membina hubungan baik dan berpartisipasi aktif dalam meningkatkan kualitas hidup masyarakat di sekitarnya.

c. Lingkungan Kerja. Membina hubungan baik dengan semua orang di lingkungan kerja serta menjaga ketertiban, kerapian dan kebersihan lingkungan kerja.

Saat ini perusahaan dihadapkan pada permasalahan penurunan prestasi kerja karyawan yang menyebabkan kinerja perusahaan secara keseluruhan juga terpengaruh. Penurunan prestasi kerja karyawan paling menonjol ditunjukkan oleh adanya pekerjaan yang berhubungan dengan perbaikan kerusakan yang tertunda disebabkan oleh tidak maksimalnya kerja 
karyawan. Prestasi kerja yang kurang memuaskan tersebut ditunjukkan oleh penyelesaian pekerjaan yang tidak sesuai jadwal, terutama pekerjaan berkaitan dengan perbaikan jaringan listrik Jawa-Bali yang ada di Surabaya. Dapat dikatakan bahwa budaya yang berfungsi sebagai tools atau alat bagi perusahaan dalam menjalankan kebijaksanaan strategis tidak berjalan dengan baik.

Penelitian dengan topik yang sama pernah dilakukan oleh Chen (2004) dengan judulExamining the Effect of Organization Culture and Leadership Behaviors on Organizational Commitment, Job Satisfaction and Job Performance at Small and MidleSized Firm of Taiwan. Hasil penelitian menunjukkan bahwa budaya organisasi bertanggung jawab organisasi dan komitmen karyawan.Pimpinan mempengaruhi interaksi antara karyawan dan pimpinan dan budaya organisasi. Variabel yang digunakan dalam penelitian ini adalah job performance dan organizational commitment sebagai variabel endogen, sedangkan variabel leadership behaviors dan job satisfaction digunakan sebagai variabel intervening dan organizational culture digunakan sebagai variabel eksogen.

Penelitian dilakukan pada 84 perusahaan kecil menengah dan perusahaan manufaktur di Taiwan dengan jumlah karyawan 1.451 orang. Sebanyak 927 responden dari 57 perusahaan telah mengembalikan kuesioner. Dari 927 kuesioner diperoleh 749 dinyatakan valid yang berasal dari 34 perusahaan manufaktur dan 23 perusahaan jasa.Hasil korelasi mengindikasikan bahwa terdapat hubungan positif antara kepemimpinan transformational dan organizational culturedan job satisfaction tapi tidak ada hubungan signifikan kinerja karyawan. Terdapat hubungan positif antara organizational culture dan job satisfaction, tapi tidak ada hubungan signifikan dengan kinerja karyawan.

Persamaan ini dengan penelitian terdahulu adalah sama-sama meneliti pengaruh budaya organisasi terhadap kinerja karyawan dan alat analisis berupa path analysis. Perbedaan diantara keduanya terletak pada sample yang diteliti dan alat uji yang digunakan. Sampel pada penelitian ini adalah karyawan PT PJB, sedangkan dalam penelitian terdahulu adalah karyawan perusahaan kecil menengah di Taiwan. Penelitian ini menggunakan variabel budaya perusahaan, motivasi dan prestasi kerja, sedangkan penelitian terdahulu menggunakan variabel organization culture and leadership behaviors on organizational commitment, job satisfaction and job performance.

Hubungan antara budaya perusahaan terhadap motivasi diajukan oleh Forstenlechner dan Lettice (2007) dengan judul: "Cultural differences in motivating global knowledge workers". Penelitian dilakukan 25 lebih kantor pengacara yang kuat pada 15 negara dan kemudian dianalisis perbedaan motivasi dan biayanya. Hasil penelitian menunjukkan perbedaan nyata pengacara untuk memotivasi dalam transfer ilmu pengetahuan. Prospek karier, otoritas, provisi, perbedaan penghargaan diantara kantor pengacara sedunia. Hasil penelitian ini menunjukkan bahwa terdapat perbedaan motivasi diantara budaya persuhaan yang berbeda. Dapat disampaikan bahwa budaya perusahaan berpengaruh terhadap motivasi karyawan.

Persamaan ini dengan penelitian terdahulu adalah sama-sama meneliti pengaruh budaya organisasi terhadap motivasi karyawan. Perbedaan diantara keduanya terletak sample yang diteliti dan alat uji yang digunakan. Sampel pada penelitian ini adalah karyawan PT PJB, sedangkan dalam penelitian terdahulu adalah pengacara yang berasal dari berbagai kantor pengacara dan negara. Peneltian ini menggunakan alat bantu analisis berupa path analysis dengan variabel endogen adalah prestasi kerja karyawan, sedangkan penelitian terdahulu menggunakan alat bantu regresi.

\section{LANDASAN TEORI DAN HIPOTESIS}

\section{Budaya Organisasi}

Seperti yang telah disinggung sedikit di pendahuluan bahwa budaya organisasi merupakan suatu tools bagi perusahaan dalam menjalankan kebijaksanaan strategis yang berperan dalam mendorong, meningkatkan kualitas, motivasi serta prestasi kerja karyawan. Adapun inti dari budaya organisasi itu sendiri meliputi artifak, kepercayaan, norma, nilai dan alasan yang dianut anggota organisasi dalam mencapai tujuannya.

Menurut Newstrom \& Davis (2002) budaya organisasi merupakan refleksi dari organisasi formal maupun organisasi informal yang terbentuk di dalam organisasi yang bersangkutan, yang kesemuanya itu membentuk norma-norma, kepercayaan atau persepsi bersama yang nantinya dianut oleh seluruh anggota organisasi. Menurut Narayana \& Nath (1993) budaya organisasi adalahBudaya perusahaan didefinisikan sebagai pola dari artifak, kepercayaan, norma, nilai dan alasan yang dipegang oleh organisasi.Schein (2010), menyatakan budaya organisasi sebagai berikut:

"A pattern of shared basic assumptions that the group learned as it solved its problem of external adaptation and internal integration, that has worked well enough to be considered valid and therefore to be tough to new members 
as the correct way to perceive, think and feel in relation to those problems"

Uttal (1983) yang dikutip oleh Daulatram (2003) mendefinisikan budaya organisasi adalah sistem dari pembagian nilai dan kepercayaan itu menarik dengan orang-orang pada sebuah perusahaan, struktur organisasi dan sistem kontrol untuk menghasilkan norma perilaku. Susanto (2008) mendefinisikan budaya adalah nilai-nilai yang menjadi pedoman sumberdaya manusia untuk menghadapi permasalahan eksternal dan usaha penyesuaian integrasi ke dalam perusahaan, sehingga masing-masing anggota organisasi harus memahami nilai-nilai yang ada dan bagaimana mereka harus bertindak atau berperilaku.

Molenaar (2002), Kotter dan Hasket (1992) yang dikutip oleh Koesmono (2005) mengatakan bahwa "Budaya mempunyai kekuatan yang penuh, berpengaruh pada individu dan kinerjanya bahkan terhadap lingkungan kerja." Menurut Atmosoeprapto (2001) Budaya Organisasi terbentuk ditentukan oleh beberapa unsur, yaitu:

1. Lingkungan usaha, di mana perusahaan itu beroperasi akan menentukan apa yang harus dikerjakan oleh perusahaan tersebut untuk mencapai keberhasilan.

2. Nilai-nilai (values), merupakan konsep dasar dari keyakinan dari suatu organisasi.

3. Panutan/keteladanan, orang-orang yang menjadi panutan atau teladan karyawan lainnya karena keberhasilannya.

4. Upacara-upacara (rites dan ritual), acara-acara rutin yang diselenggarakan oleh perusahaan dalam rangka memberikan penghargaan pada karyawannya.

5. Jaringan (Network), jaringan komunikasi informal di dalam perusahaan yang dapat menjadi sarana penyebaran nilai-nilai dari budaya perusahaan."

Robbins (1996) menjelaskan bahwa "terbentuknya budaya suatu organisasi bermula dari budaya asli diturunkan dari filsafat pendirinya." Bagan terbentuk- nya budaya organisasi menurut Robbins (1996) seperti pada Gambar 1.

Dari beberapa pendapat diatas bisa disimpulkan bahwa budaya organisasi umumnya menekankan pada pentingnya nilai-nilai yang dianut bersama. Hal tersebut akan dipatuhi oleh anggota organisasi, yang nantinya bisa mempengaruhi perilaku anggota organisasi. Dari penjabaran tersebut dibuat hipotesis:

H1: Budaya perusahaan berpengaruh signifikan terhadap motivasi kerja karyawan PTPembangkitan Jawa-Bali Surabaya unit pelayanan pemeliharaan.

\section{Motivasi Kerja}

Motivasi kerja merupakan sesuatu yang mendorong seseorang untuk melakukan suatu hal dalam pencapaian tujuan, hal ini sesuai dengan yang dikatakan oleh (Robbins, 2003) motivasi kerja adalah kondisi internal yang spesifik dan mengarahkan perilaku seseorang ke suatu tujuan. Siagian (2006) mendefinisikan motivasi kerja sebagai daya pendorong yang menyebabkan seseorang individu mau dan rela untuk mengerahkan kemampuan melakukan kegiatan yang menjadi tanggung jawabnya.

Pengetahuan tentang motivasi kerja perlu dimiliki oleh setiap pimpinan atau setiap karyawan yang bekerja dengan bantuan orang lain dan yang bekerja dengan orang lain. Karena pada dasarnya pemotivasian pada organisasi atau perusahaan oleh manajemen adalah merupakan suatu keterampilan dalam memadukan kepentingan organisasi atau perusahaannya, sehingga kerugian-kerugian dari karyawan dapat terpuaskan bersama dengan tercapainya sasaran-sasaran organisasi atau perusahaan tersebut. Beberapa ahli mempunyai pendapat yang berbeda tentang pengertian motivasi kerja yaitu antara lain: motivasi kerja merupakan hal yang sederhana karena orang-orang pada dasarnya terdorong untuk berperilaku dengan cara tertentu yang dirasakan

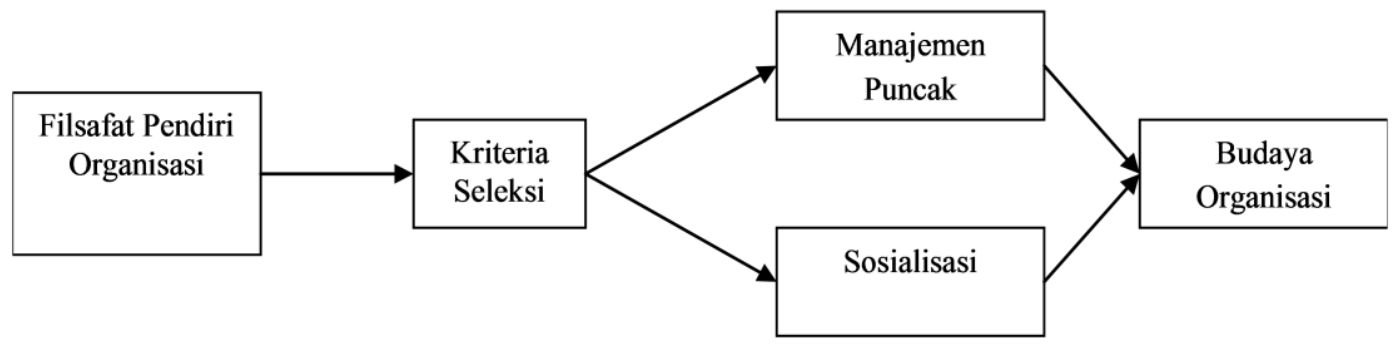

Gambar 1. Terbentuknya Budaya Organisasi

Sumber: Robbins (1996). 
mengarah pada perolehan imbalan (Siagian, 2006). Jika seseorang didorong, maka akan terpacu untuk mewujudkannya. Karyawan melakukan hal tersebut karena mempunyai keharusan untuk melakukan hal itu. Jika dimotivasi karyawan akan memilih pilihan yang positif bagi kebutuhannya, sebab karyawan melihat perilaku yang demikian itu bermakna pada dirinya, contohnya: karyawan merasa puas terhadap kebutuhannya.

Penulis lain yaitu Luthans (2006) mengatakan: "A motive is an inner state that energizes, activities or moves, and direct or change behavior toward goal". Dari kutipan tersebut dikatakan bahwa, motivasi adalah suatu keadaan di dalam diri seseorang yang mendorong, mengaktifkan dan menggerakkan atau menyalurkan perilaku kearah tujuan.Berdasarkan pendapat-pendapat para ahli di atas dapat diambil kesimpulan atas pengertian motivasi kerja adalah sesuatu yang menyebabkan atau yang menjadikan alasan mengapa kita berbuat sesuatu.

Manusia merupakan unsur terpenting dan paling menentukan bagi kelancaran jalannya proses manajemen, maka hal-hal yang berhubungan dengan motivasi kerja perlu mendapat perhatian yang sungguh-sungguh dari setiap pimpinan guna keberhasilan suatu organisasi dalam mewujudkan usaha kerjasama manusia. motivasi kerja mempunyai peranan yang penting bagi pimpinan organisasi untuk menggerakan, mengerahkan dan mengarahkan segala sumber daya dan potensi tenaga kerja yang ada kearah pemanfaatan yang paling optimal sesuai dengan batas-batas kemampuan manusia. Dari hal tersebut bisa dibuat hipotesis:

H2: Motivasi kerja berpengaruh signifikan terhadap prestasi kerja karyawan PT Pembangkitan JawaBali Surabaya unit pelayanan pemeliharaan.

\section{Prestasi Kerja}

Prestasi kerja memiliki pengertian sebagai hasil kerja yang dicapai oleh seorang pegawai dalam melaksanakan pekerjaan yang dibebankan kepadanya. Menurut Mangkunegara (2001) bahwa "prestasi kerja adalah hasil kerja secara kualitas dan kuantitas yang dicapai oleh seorang pegawai dalam melaksanakan tugasnya sesuai dengan tanggung jawab yang diberikan kepadanya". Motif prestasi kerja adalah suatu dorongan dalam diri karyawan untuk melakukan suatu kegiatan atau tugas dengan sebaik-baiknya agar mampu mencapai perestasi kerja dengan predikat terpuji (Mangkunegara, 2005). Faktor yang mempengaruhi prestasi kerja adalah penguasaan tugas, kedisiplinan kerja, pencapaian target pekerjaan, tanggung jawab terhadap perkerjaan, semangat kerja, kontribusi ide terhadap kerja dalam tim, serta kemampuan bekerjasama dengan karyawan lain.
Menurut Mitraniet al. (1995) prestasi kerja adalah hasil suatu proses atau seperangkat proses yang menciptakan pemahaman bersama mengenai apa yang harus dicapai dan bagaimana hal itu harus dicapai serta bagaimana hasil dari mengtur orang dengan cara yang meningkatkan kemungkinan tercapainya tujuan tersebut. Menurut As'ad (2002), pengertian prestasi kerja adalah tingkat sejauh mana keberhasilan seseorang didalam melakukan pekerjaannya dinamakan level of job performance.

Dari definisi-definisi di atas, bisa dilihat bahwa pengukuran prestasi kerja ini perlu dilakukan untuk melihat sejauh mana anggota organisasi berkontribusi kepada organisasi dan langkah-langkah apa yang perlu diambil oleh organisasi atau perusahan bila prestasi anggota organisasinya tidak sesuai dengan yang diharapkan oleh organisasi.

\section{Pengaruh Budaya Organisasi Terhadap Prestasi Kerja Dan Motivasi}

Kotter \& Heskett (1992) dalam teori strong culture rnenyatakan sebagai berikut:

"... Budaya Perusahaan yang kuat akan berpengaruh positif terhadap kinerja bisnis karena dapat memberikan motivasi luar biasa pada karyawan. Dengan budaya perusahaan yang kuat berarti karyawan dalam perusahaan merniliki nilai keyakinan pada nilai-nilai budaya yang sama. Hal ini akan menciptakan suatu lingkungan kerja yang nyaman dimana karyawan merasa dihargai, sehingga timbul motivasi karyawan untuk loyal terhadap perusahaan yang pada akhirnya mendorong mereka meraih prestasi kerja yang diingini perusahaan ...."

Uraian diatas merupakan bagian dari konsep mengenai kekuatan budaya yang menjelaskan bahwa budaya perusahaan yang kuat akan membimbing tiaptiap individu dan kelompok kearah yang sama, menciptakan lingkungan kerja yang nyaman dan memberikan kebebasan berinovasi bagi karyawan, hal-hal tersebut berdampak postif pada kinerja perusahaan secara umum.

Robbins (1996) menggambarkan hubungan antara budaya perusahaan dan prestasi kerja dalam sebuah model (Gambar 2). Dalam model tersebut, anggota organisasi membentuk suatu persepsi keseluruhan mengenai organisasi berdasarkan faktorfaktor karakteristik budaya perusahaan. Persepsi inilah yang secara keseluruhan menjadi budaya yang kuat dan yang lemah dari suatu perusahaan dan kemudian akan berpengaruh terhadap prestasi kerja. 


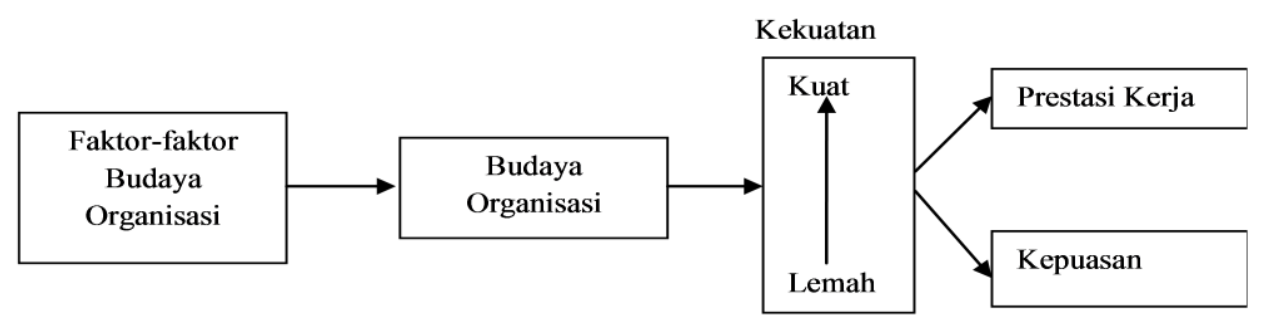

Gambar 2. Hubungan Budaya Organisasi dan Prestasi Kerja

Sumber: Robbins (1996)

Menurut Robbins (1997) budaya organisasi kuat adalah budaya yang mana nilai-nilai inti organisasi dipegang secara intensif dan dianut bersama secara meluas anggota organisasi. Faktor-faktor yang menentukan kekuatan budaya organisasi, antara lain:

1. Kebersamaan yaitu nilai-nilai yang dianut secara bersama-sama. Mulai dari manajemen puncak hingga level bawah jabatan yang ada di perusahaan menganut nilai-nilai yang sama. Semua anggota organisasi memandang, memahami dan menghayati nilai-nilai yang sama.

2. Intensitas yaitu seberapa sering nilai-nilai itu dimunculkan sebagai sikap dan perilaku oleh anggota organisasi.

Lebih lanjut Robbins (1997) mengemukakan bahwa ciri-ciri budaya kuat, yaitu:

a. Anggota-anggota organisasi loyal kepada organisasi

b. Pedoman bertingkah laku bagi orang-orang di dalam perusahaan digariskan dengan jelas, dimengerti, dipatuhi dan dilaksanakan oleh orangorang di dalam perusahaan sehingga orang-orang yang bekerja menjadi sangat kohesif.

c. Nilai-nilai yang dianut organisasi tidak hanya berhenti pada slogan, tetapi dihayati dan dinyatakan dalam tingkah laku sehari-hari secara konsisten oleh orang-orang yang bekerja dalam perusahaan.

d. Organisasi memberikan tempat khusus kepada pahlawan-pahlawan organisasi dan secara sistematis menciptakan bermacam-macam tingkat pahlawan.

e. Dijumpai banyak ritual, mulai dari ritual sederhana hingga yang mewah.

f. Memiliki jaringan kultural yang menampung cerita-cerita kehebatan para pahlawannya.

Ciri-ciri budaya organisasi lemah menurut Deal dan Kennedy:

a. Mudah terbentuk kelompok-kelompok yang bertentangan satu sama lain. b. Kesetiaan kepada kelompok melebihi kesetiaan kepada organisasi.

c. Anggota organisasi tidak segan-segan mengorbankan kepentingan organisasi untuk kepentingan kelompok atau kepentingan diri sendiri.

Beaumont (1993) mengemukakan bahwa pada organisasi yang memandang bahwa sumber daya manusia sebagai keunggulan kompetitif organisasi yang utama, terdapat korelasi positif antara budaya organisasi yang kuat dengan prestasi kerja organisasi (organizational performance). Beaumont (1993) menjelaskan bahwa implementasi dari budaya organisasi yang kuat, yaitu dalam bentuk budaya yang melandasi terbentuknya keterampilan kepemimpinan dan keterampilan manajerial individu akan meningkatkan motivasi dan komitmen individual karyawan pada pekerjaan. Dengan begitu bisa dibuat hipotesis:

H3: Budaya perusahaan berpengaruh signifikan terhadap prestasi kerja karyawan PT Pembangkitan Jawa-Bali Surabaya unit pelayanan pemeliharaan.

Mempertegas hubungan motivasi kerja dengan prestasi kerja, menurut pendapat Kossen (1991), "Expectancy theorysuggest that people behave in a certain way because they expect certain results from that behavior". Artinya adalah karyawan berperilaku dengan cara tertentu karena karyawan mengharapkan hasil tertentu dari perilakunya. Dengan adanya harapan, karyawan akan termotivasi untuk menggunakan kemampuan dalam mencapai prestasi yang diharapkan oleh badan usaha. Setiap karyawan dalam organisasi melaksanakan tugas sesuai dengan yang diharapkan darinya yang terungkap baik secara formal ataupun informal sebagai suatu pengharapan yang dikomunikasikan secara terus menerus, yang mana dalam komunikasi tersebut terdapat janji-janji berupa penghargaan dan sanksi sebagai konsekuensi dapat terpenuhi atau tidaknya pengharapan karyawan. Pengharapan tersebut tidak terlepas dari motivasi dan kemampuan karyawan dalam mencapai prestasi kerja. 
H3

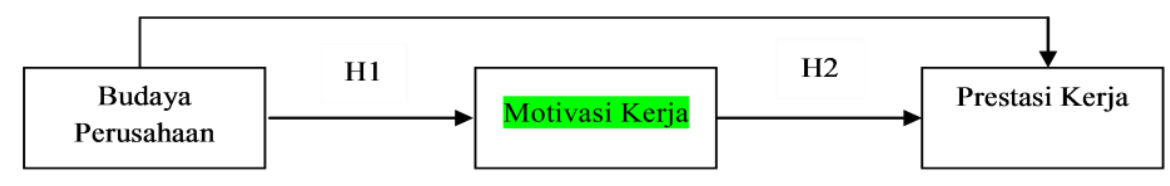

Gambar 3. Kerangka Berpikir

\section{Kerangka Berpikir}

Berdasarkan tujuan penelitian dan landasan teori yang telah dikemukakan sebelumnya, maka disusunlah kerangka berpikir penelitian serta hubungan antara variabel dalam sebuah model analisis seperti Gambar 3.

\section{METODE PENELITIAN}

\section{Pendekatan Penelitian}

Sesuai dengan tujuan penelitian yaitu untuk mengetahui pengaruh budaya perusahaan terhadap prestasi kerja karyawan dengan motivasi kerja sebagai variabel intervening, serta mengacu pada rumusan masalah dan hipotesis yang telah ditetapkan, maka penelitian ini menggunakan pendekatan kuantitatif. Dalam pendekatan kuantitatif-penelitian menggunakan proses rasionalisasi dari suatu fenomena yang terjadi dan mengukur variabel (indikator variabel) yang sedang diteliti dan akhirnya pendekatan kuantitatif mencoba untuk membuat kesimpulan yang digeneralisasikan.

\section{Prosedur Penentuan Sampel}

a). Populasi adalah wilayah generalisasi yang terdiri atas: obyek/subyek yang mempunyai kualitas dan karakteristik tertentu yang ditetapkan oleh peneliti untuk dipelajari dan kemudian ditarik kesimpulannya (Sugiyono, 1999). Populasi dalam penelitian ini adalah seluruh karyawan PT Pembangkitan Jawa-Bali Surabaya unit pelayanan pemeliharaan yang berjumlah 147 karyawan. Teknik penentuan sampel pada penelitian ini menggunakan systematic random sampling. Hal ini dilakukan karena jumlah populasi terlalu besar, sehingga pengambilan sampel menggunakan rumus dari Umar (2001).

$$
\mathrm{n}=\frac{\mathrm{N}}{1+\mathrm{N}(\mathrm{e})^{2}}
$$

$$
\mathrm{n}=\frac{147}{1+147(0.1)^{2}}=60 \text { responden }
$$

b) Sampel adalah bagian dari jumlah dan karakteristik yang dimilki oleh populasi tersebut (Sugiyono, 1999). Dalam penelitian ini jumlah sampel yang dibutuhkan sebanyak 60 responden.

\section{Teknik Analisis}

Analisis didasarkan pada data-data yang diperoleh dari sumber intern perusahaan dan hasil kuesioner yang disebarkan. Prosedur yang dilakukan adalah menilai hasil kuesioner dan mengolahnya dengan path analysis.

\section{Path Analysis}

Sesuai dengan tujuan penelitian, maka uji statistika yang digunakan yang digunakan adalah path analysis. Uji ini dimaksudkan untuk menerangkan akibat langsung dan tidak langsung seperangkat variabel, sebagai variabel penyebab, terhadap variabel akibat (Al-Rasyid, 1994).

\section{Evaluasi Model}

Hair, et al. (2010) menjelaskan bahwa pola "confirmatory" menunjukkan prosedur yang dirancang untuk mengevaluasi utilitas hipotesishipotesis dengan pengujian fit antara model teoritis dan data empiris. Jika model teoritis menggambarkan "good fit" dengan data, maka model dianggap sebagai yang diperkuat. Sebaliknya, suatu model teoritis tidak diperkuat jika teori tersebut mempunyai suatu "poor fit" dengan data. Amos dapat menguji apakah model "good fit"atau "poor fit".Jadi, "good fit" model yang diuji sangat penting dalam penggunaan path analysis.

\section{HASIL PENELITIAN DAN PEMBAHASAN}

Pengaruh variabel-variabel yang diteliti yaitu hasil pengujian perhitungan hipotesis antar variabel. Untuk selengkapnya dapat dilihat pada Tabel 1. 
Tabel1. Hasil Perhitungan Path

\begin{tabular}{llcccccc}
\hline \multicolumn{1}{c}{ Variabel } & & Variabel & Estimate & Standardized & CR & P & Keterangan \\
\hline Budaya Perusahaan $(\mathrm{X})$ & $\Rightarrow$ & Motivasi Kerja $(\mathrm{Z})$ & 0,368 & 0,365 & 3,016 & 0,003 & Signifikan \\
Budaya Perusahaan $(\mathrm{X})$ & $\Rightarrow$ & Prestasi Kerja $(\mathrm{Y})$ & 0,197 & 0,214 & 2,334 & 0,020 & Signifikan \\
Motivasi Kerja $(\mathrm{Z})$ & $\Rightarrow$ & Prestasi Kerja $(\mathrm{Y})$ & 0,592 & 0,649 & 7,074 & 0,000 & Signifikan \\
\hline \multicolumn{1}{c}{ Variabel } & & Variabel & & Variabel & & Estimate \\
\hline Budaya Perusahaan $(\mathrm{X})$ & $\Rightarrow$ Motivasi Kerja $(\mathrm{Z})$ & $\Rightarrow$ & Prestasi Kerja $(\mathrm{Y})$ & & 0,218 \\
\hline
\end{tabular}

Sumber: SPSS

Dari tabel hasil pengujian hipotesis diatas tentang adanya pengaruh budaya perusahaan dan motivasi kerja terhadap prestasi kerja karyawan, dapat diartikan bahwa jika budaya perusahaan meningkat makamotivasi kerja juga akan meningkat dan sebaliknya jika budaya perusahaan menurun, maka motivasi kerja juga akan menurun.

\section{Pembahasan}

Variabelbudaya perusahaan (X) berpengaruh langsung terhadap prestasi kerja karyawan PT Pembangkitan Jawa-Bali Surabaya sebesar 0,197 atau sebesar 19,7\% dan nilai CR sebesar 2,334. Hal ini dapat dipahami bahwa dengan budaya perusahaan yang semakin baik berarti akan mampu meningkatkan prestasi kerja karyawan, namun jika budaya perusahaan yang diterapkan PT Pembangkitan JawaBali Surabaya kurang baik, maka akan sulit untuk meningkatkan prestasi kerja karyawan PT Pembangkitan Jawa-Bali Surabaya unit pelayanan pemeliharaan.

Berdasarkan pengamatan dilapangan karyawan PT Pembangkitan Jawa-Bali Surabaya unit pelayanan pemeliharaan merasa budaya perusahaan tinggi karena perusahaan telah menerapkan peraturan di dalam setiap organisasi baik formal maupun informal seperti menerapkan jam kerja yang terbagi dalam dua shift dari pukul 08.00 sampai dengan pukul 17.00, pukul 17.00 sampai dengan pukul 01.00 dan sisa jam kerja dihitung lembur, pemakaian peralatan kerja seperi helm, sarung tangan, sedangkan peraturan informal seperti memberikan salam antar karyawan agar setiap karyawan dapat saling akrab, menerapkan nilai-nilai yang dianut perusahaan seperti adanya penghargaan dari perusahaan untuk karyawan yang mempunyai prestasi kerja yang tinggi seperti promosi jabatan, menerapkan suasana kehidupan organisasi secara menyeluruh yang tercermin dalam setiap hubungan antara anggota organisasi seperti adanya kerja tim yang baik, sehingga dapat cepat tanggap apabila ada keluhan dari pelanggan PLN.

Hal ini sesuai dengan pendapat Robbins (1996) yang mengatakan bahwa "organisasi membentuk suatu persepsi keseluruhan mengenai organisasi berdasarkan faktor-faktor karakteristik budaya perusahaan. Persepsi inilah yang secara keseluruhan menjadi budaya yang kuat dan yang lemah dari suatu perusahaan dan kemudian akan berpengaruh terhadap prestasi kerja.

Pengujian peran motivasi kerja sebagai variabel intervening ditunjukkan oleh besarnya pengaruh tidak langsung sebesar 0,218 lebih besar dari pengaruh langsung sebesar 0,198. Hal ini, berarti perusahaan harus mengelola dan atau menerapkan peraturanperaturan perusahaan, nilai-nilai perusahaan dan iklim perusahaan yang merupakan suasana kehidupan dari organisasi. Bila dibandingkan perusahaan hanya menerapkan budaya perusahaan, maka karyawan dapat menghasilkan prestasi kerja secara optimal. Karyawan merasa diberikan kebebasan untuk mengaktualisasikan diri pada pekerjaan yang akan dilaksanakannya.

Hal ini sesuai dengan pendapat Kossen (1991) yang menyatakan bahwa "Expectancy theory suggest that people behave in a certain way because they expect certain results from that behavior'. Artinya adalah karyawan berperilaku dengan cara tertentu karena karyawan mengharapkan hasil tertentu dari perilakunya. Dengan adanya harapan, karyawan akan termotivasi untuk menggunakan kemampuan dalam mencapai prestasi yang diharapkan oleh badan usaha. Setiap karyawan dalam organisasi melaksanakan tugas sesuai dengan yang diharapkan darinya yang terungkap baik secara formal ataupun informal sebagai suatu pengharapan yang dikomunikasikan secara terus menerus, di mana dalam komunikasi tersebut terdapat janji-janji berupa penghargaan dan sanksi sebagai konsekuensi dapat terpenuhi atau tidaknya pengharapan karyawan. Pengharapan tersebut tidak terlepas dari motivasi dan kemampuan karyawan dalam mencapai prestasi kerja.

\section{SIMPULAN DAN SARAN}

Setelah dilakukan pengujian atas hipotesis yang diajukan, maka diperoleh kesimpulan:Terdapat pengaruh yang signifikan variabel budaya perusahaan terhadap motivasi kerja karyawan PT Pembangkitan Jawa-Bali Surabaya unit pelayanan pemeliharaan sebesar 0,368; Terdapat pengaruh yang signifikan variabel budaya perusahaan terhadap prestasi kerja 
karyawan PT Pembangkitan Jawa-Bali Surabaya unit pelayanan pemeliharaan sebesar 0,197; Terdapat pengaruh yang signifikan variabel motivasi kerja terhadap prestasi kerja karyawan PT Pembangkitan Jawa-Bali Surabaya unit pelayanan pemeliharaan sebesar 0,592.

Sebagai bagian akhir dari penelitian ini, maka saran yang dapat disampaikan antara lain:

- Hasil penelitian ini menemukan bahwa terdapat pengaruh budaya perusahaan terhadap motivasi kerja karyawan PT Pembangkitan Jawa-Bali Surabaya unit pelayanan pemeliharaan, selain itu budaya perusahaan juga berpengaruh terhadap prestasi kerja karyawan. Melihat hasil temuan yang demikian dapat disampaikan bahwa peran budaya perusahaan besar dalam membentuk motivasi dan prestasi kerja karyawan, sedangkan karyawan unit pelayanan pemeliharaan adalah bagian penting dalam perusahaan yang memberikan pelayanan pada PLN. Namun demikian terdapat budaya organisasi yang dipersepsikan relatif rendah, yaitu iklim perusahaan yang hanya sebesar 3,95, sehingga pihak manajemen dapat menciptakan iklim perusahaan yang mendukung terciptanya motivasi kerja dan mendorong perbaikan prestasi kerja karyawan. Transparansi bisa merupakan faktor penentu iklim perusahaan menjadi baik. Manajemen dapat memulai dengan transparansi kriteria yang digunakan untuk promosi, tunjangan, insentif, kenaikan gaji, sanksi dan reward atau punishmentsystem yang lain. Pemahaman karyawan akan kriteria-kriteria tersebut akan menyebabkan tidak adanya kecemburuan di kalangan karyawan yang menyebabkan iklim kerja membaik, sehingga motivasi dan prestasi kerja karyawan meningkat.

- Untuk lebih meningkatkan motivasi kerja karyawan unit pelayanan pemeliharaan agar prestasi kerja meningkat, maka diperlukan informasi tentang faktor-faktor apa yang membuat karyawan termotivasi. Karyawan dengan usia muda biasanya lebih suka menyukai tantangan, sehingga penugasan yang mengandung tantangan akan lebih memotivasi dibandingkan pekerjaan yang bersifat rutin. Perlu digali lagi informasi yang membuat karyawan lain termotivasi, sehingga kebijakan yang diambil tepat, motivasi meningkat dan prestasi kerja karyawan juga meningkat.

\section{DAFTAR REFERENSI}

Al-Rasyid, H. 1994. Teknik Penarikan Sampel dan Penyusunan Skala. Bandung: Program Pascasarjana UNPAD.

As'ad, M. 2002. Psikologi Industri. Edisi Keempat. Yogyakarta: Liberty.
Atmosoeprapto, K. 2001. Produktivitas Aktualisasi Budaya Perusahaan. Jakarta: PT Elex Media Komputindo Kelompok Gramedia.

Beaumont, P.B. 1993. Human Resources Management: Key, Concept and Skill. London: Sage Publication Ltd.

Caudron, S. 2003. HR is dead-Long live HR. Workforce, 82(1): 26-30.

Chen, L. Y. 2004. Examining the Effect of Organization Culture and Leadership Behaviors on Organizational Commitment, Job Satisfaction and Job Performance at Small And Midle-Sized Firm of Taiwan.Journal of American Academy of Business, Cambridge,5(1): 432-439.

Daulatram, B. L. (2003). Organizational Culture and Job Satisfaction. Journal of Businessand Industrial Marketing, 18(3): 219-236.

Forstenlechner, I. \&Lettice, F.2007. Cultural differences in motivatin global knowledge workers. Equal Opportunities International,26(8): 823833.

Hair Jr., J. F., Black, W. C., Babin, B. J. \& Anderson, R. E. 2010.Multivariate Data Analysis. New Jersey: Prentice Hall International.

Koesmono, T. 2005.Pengaruh Budaya Organisasi Terhadap Motivasi Dan Kepuasan Kerja Serta Kinerja Karyawan Pada Sub Sektor Industri Pengolahan Kayu Skala Menengah Di Jawa Timur.Jurnal Manajemen dan Kewirausahaan, 7(2): 162-179.

Kossen. 1991. Human Resources Management. Fourth Edition.New York: Prentice Hall, Inc.

Kotter, J.\&Heskett. 1992. Organizational Behavior. Sixth Edition. New York: Prentice Hall, Inc.

Luthans, F. 2006. Organizational Behavior. Fifth Edition, New York: McGraw-Hill International.

Mangkunegara, A. P. 2001. Manajemen Sumber Daya Manusia Perusahaan. Bandung: PTRemaja Rosdakarya.

-------. 2005. Manajemen Sumber Daya Manusia Perusahaan. Bandung: PT Remaja Rosdakarya.

Mitrani, A, Daziel, M. \& Fitt, D. 1995. Manajemen Sumber Daya Manusia Berdasarkan Kompetensi. Jakarta: Pustaka Utama Grafiti.

Narayana, V.K. \& Nath, R. 1993. Organizational Theory: A Strategic Approach. Homewood: Irwin.

Newstrom, J. W. \& Davis, K. 2002. Organizational Behavior Human Behavior at Work. New York: McGraw-Hill International.

Robbins, S. P. 1996.Organizational Behavior. Edisi Tujuh. Terjemahan.Jilid 1. Jakarta: Penerbit PT Bhuana Ilmu Populer. -1997. Perilaku Organisasi: Konsep, Kontroversi, Aplikasi.Terjemahan. Jilid 2. Jakarta: PT Prenhallindo. 
2003. Perilaku Organisasi: Konsep, Kontroversi, Aplikasi.Terjemahan. Jilid 2. Jakarta: PT Prenhallindo.

Schein, E. H. 2010. Organizational Culture and Leadership. Fourth Edition. San Francisco: Jossey-Bass Publisher.

Siagian, S. P. 2006. Manajemen Sumber Daya Manusia. Jakarta: Bumi Aksara.
Sugiyono. 1999. Metode Penelitian Bisnis. Cetakan Pertama. Bandung: CV Alfabeta.

Susanto, A.B. 2008. Budaya Perusahaan.Jakarta: Elex Media Komputindo Kelompok Gramedia.

Umar, H. 2001. Riset Sumber Daya Manusia Dalam Organisasi. Cetakan Kelima. Jakarta: PT Gramedia Pustaka Utama. 